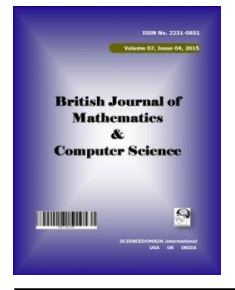

British Journal of Mathematics \& Computer Science

9(6): 537-558, 2015, Article no.BJMCS.2015.223

ISSN: 2231-0851

SCIENCEDOMAIN international

www.sciencedomain.org

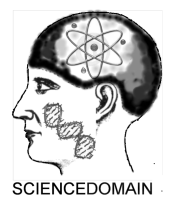

\title{
Parameters Determination for the Design of Bevel Gears Using Computer Aided Design (Bevel CAD)
}

\author{
B. O. Akinnuli ${ }^{1}$, O. O. Agboola ${ }^{*}$ and P. P. Ikubanni ${ }^{1}$ \\ ${ }^{I}$ Department of Mechanical Engineering, Landmark University, OmuAran, Kwara State, Nigeria.
}

Article Information

DOI: $10.9734 / \mathrm{BJMCS} / 2015 / 18411$

$\underline{\operatorname{Editor}(s):}$

(1) Dariusz Jacek Jakóbczak, Chair of Computer Science and Management in this department, Technical University of Koszalin,

Poland.

Reviewers:

(1) Anonymous, Duzce University, Turkey.

(2) Wang yong, Mechanical Department, TianJin University of Commerce, China. Complete Peer review History: http://sciencedomain.org/review-history/9852

Original Research Article

Received: 20 April 2015

Accepted: 12 May 2015

Published: 18 June 2015

\begin{abstract}
This paper prescribes a Computer Aided approach to the design of bevel gears. The approach utilizes standard design equations and standard data on bevel gears; linking them together using a Programming language $(\mathrm{C \#})$ to develop this special software (Bevel CAD) that designs and determines the strengths and dimensions of bevel gears. This study reviews the Procedural steps (algorithms) involved in the design of bevel gears and the development of the software package (Bevel CAD) which is to be used in designing bevel gears. When material required are selected based on the area of application, the software will make use of the data provided using the $\mathrm{C \#}$ to determine the required; speed and velocity of the bevel gear, number of teeth, speed ratio, dynamic load, endurance strength and maximum wear load for the design bevel gear. The Bevel CAD's performance was verified by comparing the results of Algorithm calculation and the software's results. The Bevel CAD was confirmed effective as the minor differences obtained between the results were due to approximation errors. The Bevel CAD increases productivity but reduces drudgery of enormous calculations; hence, making it a recommended tool for industries and tertiary institutions for the designing of bevel gears.
\end{abstract}

Keywords: Bevel gear; design parameters; software development; CAD.

\section{Introduction}

A machine is the combination of various elements to perform a task. In doing so, power (torque) is needed to be transferred from one element or part to another; and this can be achieved with the use of power transmitting devices such as belt drives, chain drives, gear drives. Gears lead other power transmitting devices (chain drives, belts drives, etc) because of its ability to achieve definite velocity ratio. In precision

*Corresponding author: omegawole@gmail.com; 
machines (clock), in which a definite velocity ratio is of importance, gears and other toothed wheels could be used.

A gear is a rotating machine element having cut teeth (or cogs) which mesh with another toothed part in order to transmit torque. Geared devices can change the speed, torque, and direction of a power source. According to [1], gear is one of the most important devices used in many types of machinery. Gears allow the user to translate power, motion and torque. Gears have a power transmission efficiency of up to $98 \%$ and are some of the most durable torque transmitting machine elements.

A bevel gear system is used for transmitting power at a constant velocity ratio between two shafts whose axes intersect at a certain angle. Gear can be used to transmit large power (small car can run on belt drives but large vehicles can't, instead gears are being used). Gears are mostly applicable to small centre distances of shafts; they possess high efficiencies; they have reliable services; gears have compact layout. These among other characteristics of gears give it edge over other power transmitting devices. Bevel gears among other gears are used for transferring torque with intersecting shafts in the same plane.

While bevel-gear CAD software is a computer software that aids engineers, bevel-gear designers, manufacturers in the design of bevel gears. Since the World is turning towards computer technology and the use of computer to alleviate human efforts; the application of computer to the engineering world is not left behind. Hence, numerous works has been done on Computer Aided Design. Gear as an important machine component has also benefitted from this technological development. Works had also been done on gear design software and improvements are being achieved on daily basis. Therefore, [2] stated that model design of the bevel and hypoid gear is an area of great research interest nowadays. Recently, modeling of spiral bevel and hypoid gear made a lot of achievement, summarized as: 1) Point-to- surface modeling by fitting discrete points on the tooth surface, during which the vital steps are the solution of the discrete points on the tooth surface and their obtainment based on derivation of the tooth surface equations. 2) line-to-surface modeling by fitting tooth profile curves, whose core areas are the equation derivations of the tooth profile curves and the output in the three-dimensional graphics software [3].

Computer Aided Design CAD was defined by [4] as any design activity that involves the use of computer to create, modify and document engineering design using interactive computer graphics systems referred to as a CAD system. Since its inception, CAD has undergone continuous development. [5] reported that by the 1970's, CAD systems were being used in many drafting application and by the mid-1970s, there was an established market for CAD. CAD has grown from a narrow activity and concept to a methodology of design activities that include computer or group of computers used to assist in the analysis, development and drawing of product components. One of the areas where CAD was employed in manufacturing technology as related to gear design is the Gear skiving where CAD simulation approach was used [6].

Also, CAD surface design can be used for rapid prototyping by sweeping or rotating, and creating the curves surface from the point cloud, a variety of new modeling and their respective optimization methods were explored. This can then compensate for some deficiencies in the previous modelings, and create new conditions for fast and accurate parametric modeling of the spiral bevel and hypoid gear [7].

\section{Bevel Gear Review}

As reported by [8], the first primitive gears can be traced back to over 3000 years ago where early gears were made from wood. They were made of wood and had teeth of engaged pins. Early Greeks used metal gears with wedge shaped teeth; Romans used gears in their mills; stone gears were used in Sweden in the Middle Ages (Gears Manufacturers). All of these cultures found reasons to use basic gearing to convert energy or motion in one form to a form they could use in devices for the technological advancement of their societies.

Gears have existed since the invention of rotating machinery. However due to their force multiplying proportions, early engineers used them for hoisting heavy loads such as building materials. The mechanical 
advantage of gears was also used for ship anchor hoist and catapults. Bevel gears are indispensable parts of drive systems found in power transmission for various machinery and equipment [9]. Due to a relatively complex geometry, continuous efforts are made to streamline the design and manufacturing process of bevel gears [10]. As a result of this, there is need for accurate modeling of spiral bevel which gives room for digitized manufacturing such as the tooth contact analysis (TCA) technology, the error correction of tooth surface technology and other key technologies [11].

According to [12], mating gear teeth acting against each other to produce rotary motion may be likened to a cam and follower. As two gears mesh, there is tendency for unwanted noise to be generated. [13] claimed that accurate tooth surface and good surface quality are critical to achieve the low-noise bevel gear drives.

Bevel gear has the numerous applications in engineering and machine design. It has several importance and applications. Among these applications are:

\subsection{The Differential Drives}

This can transmit power to two axles spinning at different speeds, such as those on a cornering automobile. The Fig. 1 below shows a typical example of a differential bevel gear.

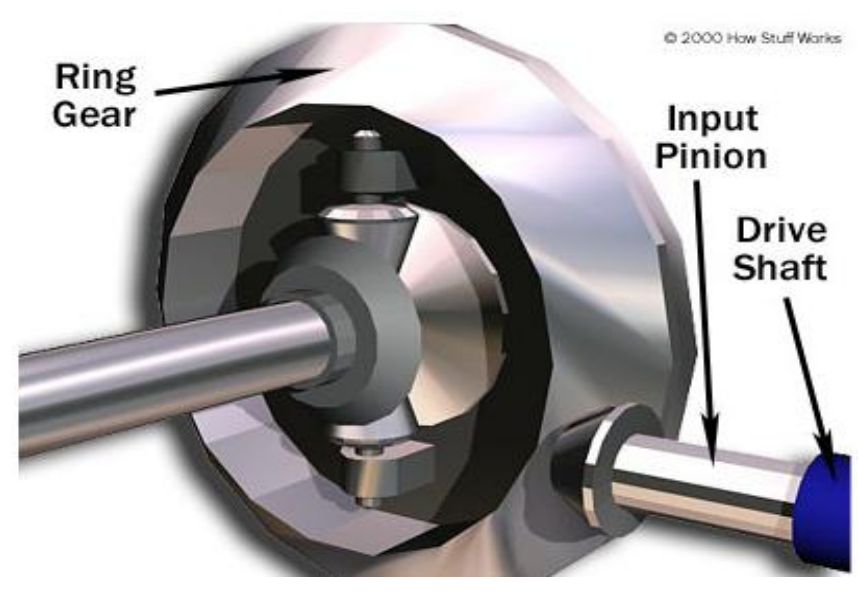

Fig. 1. Hypoid bevel gears in a car differential Source: [14]

\subsection{Dividing Head}

Dividing head used machining operations like milling gears, sprockets on milling machine.

\subsection{Hand Drill Mechanism}

Hand drill mechanism as the handle of the drill is turned in a vertical direction, the bevel gears change the rotation of the chuck to a horizontal rotation.

\subsection{Rotorcraft Drive Systems}

Spiral bevel gear are important components on this system and are used to operate at high load and high speed. In this application, spiral bevel gears are used to redirect the shaft from the horizontal gas turbine engine to the vertical rotor. 
Over the years, engineers have been coming out with various designs of bevel gears; trying to improve on their performances under various loads. This has assisted in the invention and production of machines with higher performances and efficiencies.

The bevel CAD software in discussion is a specialized software not meant for the designing of other gears or machine part unlike other multi-purpose software such AUTOCAD, INVENTOR, CATIA, PRO E. The software is mainly for the design of bevel gears. Its specialization has made this software easier and more flexible for bevel gear manufacturers and designers.

This paper aims at identifying the designed parameters required in designing bevel gear, collect relevant data for bevel gear design, develop algorithm for the steps required for the computation for each parameter, develop a software for implementing the algorithm developed and test the performance and effectiveness of the software model developed.

The numerous applications of bevel gears in machines have made its design more frequent and important. As a result of its immense importance, several works are being done on improving the efficiencies of bevel gears under static and dynamic load. This among other under-listed reasons justifies this research work:

i. Time and efforts in designing Bevel gear can be far reduced by using the BEVEL CAD software in the design. This will also assist designer focus on conception of ideas.

ii. The modeled software is more flexible and user friendly; hence, making it comprehensive and easier for designer to use.

iii. The software uses standard data and formula from renowned Engineering Textbooks; thus, making its result more reliable.

iv. The computational speed of the modeled software is comparatively better than other multipurpose CAD software such as INVENTOR, AUTOCAD etc

\section{Methodology}

\subsection{Terminologies and Design Parameters Identification}

The design of a bevel gear starts from getting acquainted with various terminologies, symbols/parameters and formulae attributed to Bevel gear. A bevel gear is shaped like a section of a cone. See Fig. 2.0 for the nomenclature of a meshed bevel gear.

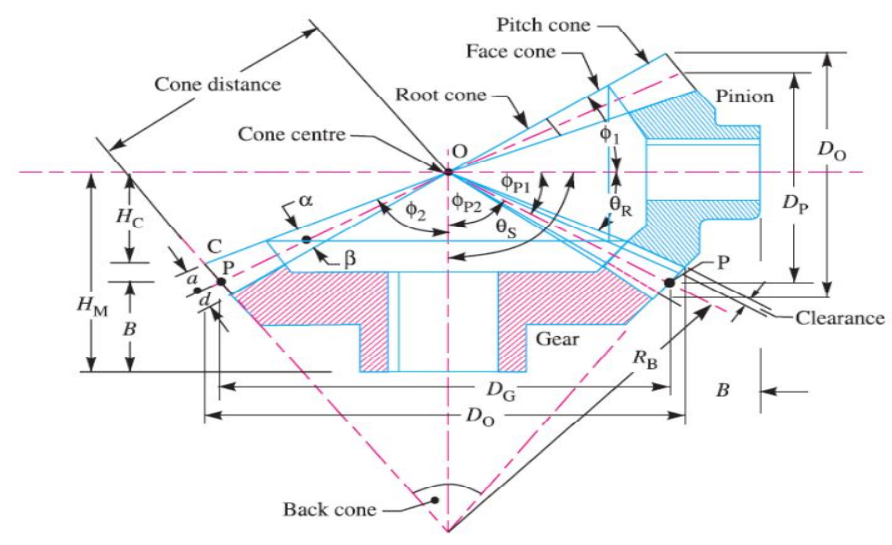

Fig. 2.0. Nomenclature of a meshed bevel gear Source: [15] 
The parameter/symbol used, description as well as the formula (as applicable) are tabulated as shown in Table 1.

Table 1.0. Parameters/symbols, description and formula used

\begin{tabular}{|c|c|c|}
\hline Symbol/Parameter & Description/Meaning (unit) & Formula \\
\hline$\sigma_{01}$ & $\begin{array}{l}\text { Allowable static stress of pinion wheel } \\
\left(\mathrm{N} / \mathrm{mm}^{2}\right)\end{array}$ & $\begin{array}{l}\text { To be determined from the } \\
\text { material used }\end{array}$ \\
\hline$\sigma_{02}$ & Allowable static stress of gear wheel $\left(\mathrm{N} / \mathrm{mm}^{2}\right)$ & $\begin{array}{l}\text { To be determined from the } \\
\text { material used }\end{array}$ \\
\hline $\mathrm{T}_{1}$ or $\mathrm{T}_{2}$ & $\begin{array}{l}\text { Number of Teeth in pinion and wheel } \\
\text { respectively }\end{array}$ & One of the two would be given \\
\hline $\mathrm{N}_{1}$ or $\mathrm{N}_{2}$ & Speed of pinion and gear respectively (rpm) & One of the two would be given \\
\hline $\mathrm{G}$ & Velocity ratio or input gear ratio (unitless) & To be given \\
\hline$\Theta_{\mathrm{s}}$ & Shaft angle $\left({ }^{\circ}\right)$ & To be given \\
\hline$\theta_{\mathrm{p} 1}$ & Pitch angle for pinion wheel $\left({ }^{\circ}\right)$ & $\tan ^{-1}\left(\frac{\sin \theta_{s}}{G+\cos \theta_{s}}\right)$ \\
\hline$\theta_{\mathrm{p} 2}$ & Pitch angle for gear wheel $\left({ }^{\circ}\right)$ & $\theta_{\mathrm{p} 2}=90^{\circ}-\theta_{\mathrm{p} 1}$ \\
\hline $\mathrm{m}$ & Module (unitless) & $\begin{array}{l}\text { To be determined from the } \\
\text { AGMA standard table for tooth } \\
\text { form }\end{array}$ \\
\hline $\mathrm{D}_{1}$ or $\mathrm{D}_{2}$ & $\begin{array}{l}\text { Diameter of pinion and wheel respectively } \\
(\mathrm{mm})\end{array}$ & $\begin{array}{l}\mathrm{mT}_{1} \text { and } \mathrm{mT}_{2} \text { where } \mathrm{m} \text { is the } \\
\text { module }\end{array}$ \\
\hline $\mathrm{d}_{\mathrm{e}}$ & Dedendum (mm) & $\begin{array}{l}\text { To be determined from the } \\
\text { AGMA standard table for tooth } \\
\text { form }\end{array}$ \\
\hline $\mathrm{a}$ & Addendum (mm) & $\begin{array}{l}\text { To be determined from the } \\
\text { AGMA standard table for tooth } \\
\text { form }\end{array}$ \\
\hline $\mathrm{T}_{\mathrm{d}}$ & Tooth depth (mm) & $\begin{array}{l}\text { To be determined from the } \\
\text { AGMA standard table for tooth } \\
\text { form }\end{array}$ \\
\hline$r_{f}$ & Fillet radius $(\mathrm{mm})$ & $\begin{array}{l}\text { To be determined from the } \\
\text { AGMA standard table for tooth } \\
\text { form }\end{array}$ \\
\hline $\mathrm{T}_{\text {th }}$ & Tooth thickness (mm) & $\begin{array}{l}\text { To be determined from the } \\
\text { AGMA standard table for tooth } \\
\text { form }\end{array}$ \\
\hline $\mathrm{D}_{\mathrm{R} 1}$ or $\mathrm{D}_{\mathrm{R} 2}$ & $\begin{array}{l}\text { Root diameter of pinion and gear respectively } \\
(\mathrm{mm})\end{array}$ & $\mathrm{D}_{1}-2 \mathrm{~d}_{\mathrm{e}}$ and $\mathrm{D}_{2}-2 \mathrm{~d}_{\mathrm{e}}$ \\
\hline $\mathrm{L}$ & Slant height of Pitch cone $(\mathrm{mm})$ & $\sqrt{\left(\frac{D_{1}}{2}\right)^{2}+\left(\frac{D_{2}}{2}\right)^{2}}$ \\
\hline $\mathrm{V}_{1 \text { or } 2}$ & Velocity of pinion or gear $(\mathrm{m} / \mathrm{s})$ & $\frac{N_{1} \pi D_{1}}{60000}$ \\
\hline
\end{tabular}

\subsection{Gear Teeth System}

A tooth system is a standard given by the American Gear Manufacturers Association (AGMA) and the American National Institute (ANSI). It specifies relationship between addendum, dedendum, working depth, tooth thickness and pressure angle to attain interchangeability of gears of a tooth number but of the same pressure angle and pitch. Gear designers should be informed of advantages and disadvantages of the various 
systems so that optimum tooth for a given design can be chosen. Basically there are four systems of gear teeth.

i $\quad 14.5^{\circ}$ Composite system

ii $14.5^{\circ}$ full involute system

iii $20^{\circ}$ full depth involute system

iv $20^{\circ} \mathrm{stub}$ involute system

Table 2.0. Standard proportion of gear system by AGMA

\begin{tabular}{|c|c|c|c|c|}
\hline \multicolumn{2}{|c|}{$\mathbf{S} / \mathbf{N}$} & $\begin{array}{l}14.5^{\circ} \text { Composite } \\
\text { or full depth } \\
\text { involute system }\end{array}$ & $\begin{array}{l}20^{\circ} \text { full depth } \\
\text { involute system }\end{array}$ & $\begin{array}{l}20^{\circ} \text { stub involute } \\
\text { system }\end{array}$ \\
\hline 1. & Addedum & $1 \mathrm{~m}$ & $1 \mathrm{~m}$ & $0.8 \mathrm{~m}$ \\
\hline 2. & Dedendum & $2.25 \mathrm{~m}$ & $1.25 \mathrm{~m}$ & $1 \mathrm{~m}$ \\
\hline 3. & Working depth & $2 \mathrm{~m}$ & $2 \mathrm{~m}$ & $1.6 \mathrm{~m}$ \\
\hline 4. & Minimum total depth & $2.25 \mathrm{~m}$ & $2.25 \mathrm{~m}$ & $1.80 \mathrm{~m}$ \\
\hline 5. & Tooth thickness & $1.5708 \mathrm{~m}$ & $1.5708 \mathrm{~m}$ & $1.5708 \mathrm{~m}$ \\
\hline 6. & Minimum clearance & $0.25 \mathrm{~m}$ & $0.25 \mathrm{~m}$ & $0.20 \mathrm{~m}$ \\
\hline 7. & Fillet radius at root & $0.4 \mathrm{~m}$ & $0.4 \mathrm{~m}$ & $0.4 \mathrm{~m}$ \\
\hline
\end{tabular}

\subsection{Lewis, Buckingham and Tregold Formula}

These equations are applied to determine the tooth form, Bevelling factor, Tooth form factor and static strength. Static strength of bevel gear is obtained by determining the following parameters.

(a) Velocity factor $C_{v}$

Velocity factor $\mathrm{C}_{\mathrm{v}}$ is determined first base on the level of cut of the gear.

$$
\begin{array}{ll}
\mathrm{C}_{\mathrm{v}}=\frac{4}{4+v} & \text { (For a carefully cut gear) } \\
\mathrm{C}_{\mathrm{v}}=\frac{3}{3+v} & \text { (For teeth cut by form cutter) } \\
\mathrm{C}_{\mathrm{v}}=\frac{6}{6+v} & \text { (For teeth generated with precision machines) }
\end{array}
$$

where $\mathrm{v}$ is the velocity in $\mathrm{m} / \mathrm{s}$ )

(b) Equivalent Number of Teeth $T_{E}$

Equivalent number of teeth for both Pinion and Gear wheel are obtained from the relations shown below respectively.

$$
\begin{aligned}
& \mathrm{T}_{\mathrm{E} 1}=\mathrm{T}_{1} \sec \theta_{\mathrm{p} 1} \\
& \mathrm{~T}_{\mathrm{E} 2}=\mathrm{T}_{2} \sec \theta_{\mathrm{p} 2}
\end{aligned}
$$

(c) Tooth form factor $Y^{\prime}$

Tooth form factor for pinion $\mathrm{Y}^{\prime}{ }_{1}=0.154-\frac{0.912}{T_{E 1}}$ 
Tooth form factor for pinion $\mathrm{Y}_{2}{ }_{2}=0.154-\frac{0.912}{T_{E 2}}$

(d) Bevel Factor B.F

B.F $=\frac{L-b}{L} \quad \ldots 6$; where $\mathrm{b}$ is the face width given as $\frac{L}{3}$

(e) Tangential Tooth Load $W_{T}$

Tangential Load for pinion $\mathrm{W}_{\mathrm{T} 1}=\sigma_{\mathrm{o} 1} \times \mathrm{C}_{\mathrm{V}} \times \mathrm{b} \square \mathrm{mY}^{\prime}{ }_{1} \times \mathrm{B} . \mathrm{F}$

Tangential Load for gear $\mathrm{W}_{\mathrm{T} 2}=\sigma_{\mathrm{o} 2} \times \mathrm{C}_{\mathrm{V}} \times \mathrm{b} \square \mathrm{mY}{ }_{2} \times$ B.F

where $\sigma_{01}$ and $\sigma_{02}$ are allowable static stress of pinion wheel and allowable static stress of gear wheel respectively.

Design condition: if $\mathrm{W}_{\mathrm{T} 1}>\mathrm{W}_{\mathrm{T} 2}$, it means that pinion teeth are weaker than gear teeth.

\subsection{Dynamic Load}

Dynamic load is mathematically expressed as the summation of incremental load due to dynamics and tangential tooth load i.e

$\mathrm{W}_{\mathrm{D}}=\mathrm{W}_{\mathrm{I}}+\mathrm{W}_{\mathrm{T}}$

where $\mathrm{W}_{\mathrm{I}}=\frac{21 v\left(b c+W_{T}\right)}{21 v+\sqrt{b c+W_{T}}}$

but $\mathrm{c}$ is a deformation factor expressed as $\mathrm{c}=\frac{0.00535}{1 / E_{1}+1 / E_{2}}$

where $E_{1}$ and $E_{2}$ are the modulus of elasticity for pinion and gear respectively

Dynamic load of pinion wheel $\mathrm{W}_{\mathrm{D} 1}=\mathrm{W}_{\mathrm{I} 1}+\mathrm{W}_{\mathrm{T} 1}$

Dynamic load of gear wheel $\mathrm{W}_{\mathrm{D} 2}=\mathrm{W}_{\mathrm{I} 2}+\mathrm{W}_{\mathrm{T} 2}$

(f) Endurance Strength

Endurance strength for pinion wheel $\mathrm{W}_{\mathrm{s} 1}=\sigma_{\mathrm{E} 1} \mathrm{~b} \exists \mathrm{mY}_{1}$ ' $\mathrm{x}$ B.F

Endurance strength for gear wheel $\mathrm{W}_{\mathrm{s} 2}=\sigma_{\mathrm{E} 2} \mathrm{~b} \exists \mathrm{mY}_{2}^{\prime} \times \mathrm{B} . \mathrm{F}$

where $\sigma_{\mathrm{E} 1}$ and $\sigma_{\mathrm{E} 2}$ are the endurance strength of the material used for pinion wear and gear wheel respectively.

(g) Wear

Maximum wear load of pinion wheel $\mathrm{W}_{\mathrm{w} 1}=\frac{\mathrm{D}_{1} \mathrm{bQ} k_{1}}{\cos \theta_{p 1}}$

Maximum wear load of gear wheel $\mathrm{W}_{\mathrm{w} 2}=\frac{D_{2} \mathrm{bQ} k_{2}}{\cos \theta_{p_{2}}}$ 
but Ratio factor $\mathrm{Q}$ is given as $\mathrm{Q}=\frac{2 T_{E 2}}{T_{E 2}+T_{E 1}}$

Load stress factor $K_{1}=\frac{\sigma_{S E 1}^{2} \times 0.3}{1.4}\left(\frac{1}{E_{1}}+\frac{1}{E_{2}}\right)$

where $\sigma_{E S 1}$ is the surface endurance limit of pinion wheel

Load stress factor $K_{2}=\frac{\sigma_{S E 2}^{2} \times 0.3}{1.4}\left(\frac{1}{E_{1}}+\frac{1}{E_{2}}\right)$

where $\sigma_{E S 2}$ is the surface endurance limit of gear wheel

Design condition: If $\mathrm{W}_{\mathrm{w} 1}>\mathrm{W}_{\mathrm{T} 1} \& \mathrm{~W}_{\mathrm{W} 2}>\mathrm{W}_{\mathrm{T} 2}$ (design is satisfactory from the standpoint of wear).

\subsection{Algorithm for the Design of Bevel Gear}

1. Declare constants for different materials (using Table 1.0)

$\sigma_{0^{-}}$Allowable static strength

$\sigma_{\mathrm{e}}-$ Allowable endurance strength

$\sigma_{\mathrm{es}}-$ Allowable surface endurance strength

E- Young modulus

\section{Select Materials and Gear Forms}

I. Select materials

II. Select tooth form $\left(14.5^{\circ}\right.$ full depth involute, $20^{\circ}$ full depth involute, $\left.20^{\circ} \mathrm{stub}\right)$

III. Select level of cut- (first class cut, carefully cut, precision cut

IV. Select forms of gear loading ( steady load, pulsating load, shock load)

3. Dimension of Bevel Gear

i. Select module from list of standard module module

ii. Enter the gear ratio

iii. Enter the number of teeth of the pinion gear

iv. Enter the ratio of slant height (l) of face width (b)

v. Determine the face width (b)

vi. Determine the pitch angle $\left(\theta \mathrm{p}_{1}\right)$ of the pinion $\theta_{\mathrm{p} 1}=\tan ^{-1} \frac{1}{\mathrm{G}}$ where $\mathrm{G}=$ velocity ratio/ gear ratio.

vii. Determine the pitch angle $\left(\theta \mathrm{p}_{2}\right)$ of gear $\theta_{p 2}=\theta_{s}-\theta_{\mathrm{p} 1}$

viii. Determine the number of teeth of the second wheel $T_{2}=G \times T_{1}$

ix. Determine the pitch diameter of gear $\left(\mathrm{D}_{\mathrm{G}}=\mathrm{m} \mathrm{X} \mathrm{T} \mathrm{T}_{\mathrm{G}}\right)$

x. Determine the pinion pitch diameter $\left(\mathrm{D}_{\mathrm{P}}=\mathrm{m} \mathrm{X} \mathrm{T} \mathrm{T}_{\mathrm{P}}\right)$

xi. Determine the tooth depth $(\mathrm{a}+\mathrm{d})$

xii. Determine root diameter $\left(D_{\mathrm{p}}-2 \mathrm{~d}\right)$

xiii. Determine the outside diameter $\left(D_{P}+2 a\right)$

4. Speed and Velocity

i. Enter velocity of pinion wheel in rpm

ii. Determine the velocity of the gear wheel $\left(\mathrm{N}_{\mathrm{P}} / \mathrm{G}\right)$

iii. Determine the pitch line velocity ' $\mathrm{v}$ ' in $\mathrm{m} / \mathrm{s}$

iv. Determine the velocity factor $\mathrm{C}_{\mathrm{V}}$ 
5. Gear Design using Tregolds, Buckingham \& Lewis Formulas

i. Select the Allowable static stress

ii. Determine the equivalent tooth form $T_{E}=T \sec \theta$

iii. Determine the bevel factor. $B \cdot F=\frac{L-b}{L}$

iv. Determine the tooth form factor $\left(\mathrm{y}^{\mathrm{l}}\right)$

v. Determine the static strength using lewis formula $\left(W_{T}=\left(\sigma_{O} C_{V}\right) b \pi m y y^{1} B . F\right)$

6. Dynamic Load

i. Determine service factor $\mathrm{C}_{\mathrm{S}}$

Determine increased load due to dynamic force $W_{I}=21 V(b C+W t) / 21 v+\sqrt{b c+W_{T}}$

ii. Determine the dynamic load $\left(\mathrm{W}_{\mathrm{D}}=\mathrm{W}_{\mathrm{T}}+\mathrm{W}_{\mathrm{I}}\right)$

7. Endurance Strength $\mathrm{W}_{\mathrm{s}}$

i. Select the endurance strength of the material selected $\left(\sigma_{\mathrm{e}}\right.$, table $)$

ii. Determine the endurance strength ( $W_{S}=\sigma_{O} b \pi m y^{l}\left(\frac{l-b}{l}\right)$ ) Conditions for endurance strength if

$W_{S} \geq 1.25 W_{D}$ (Steady load)

$W_{S} \geq 1.35 W_{D} \quad$ (Pulsating load)

$W_{S} \geq 1.5 W_{D} \quad$ (Shock load)

then design is satifactory from the standpoint of dynamics

ELSE

design is not satisfactory from the standpoint of dynamics

8. Wear Resistance/ Surface Endurance Strength

I. Determine young modulus of the pinion material (table)

II. Determine the surface endurance $\left(\sigma_{\mathrm{es}}\right)$ from ( table)

III. Determine the young modulus of gear ratio (table)

IV. Determine the stress factor $k=\frac{\sigma_{e s}{ }^{2} \sin \phi}{1.4}\left(\frac{1}{E_{P}}+\frac{1}{E_{P}}\right)$

V. Determine the limiting load for wear $W_{W}=\frac{D_{P} b Q k}{\cos \theta_{p}}$

If $\mathrm{W}_{\mathrm{w}}>\mathrm{W}_{\mathrm{t}}$ then, design is satisfactory from the standpoint of wear Else design is not satisfactory from the standpoint of wear.

\subsection{Algorithm Flowchart}

The Algorithm flow chart in Fig. 3.0 shows the stepwise procedures for the design of bevel gear using the Bevel CAD. 


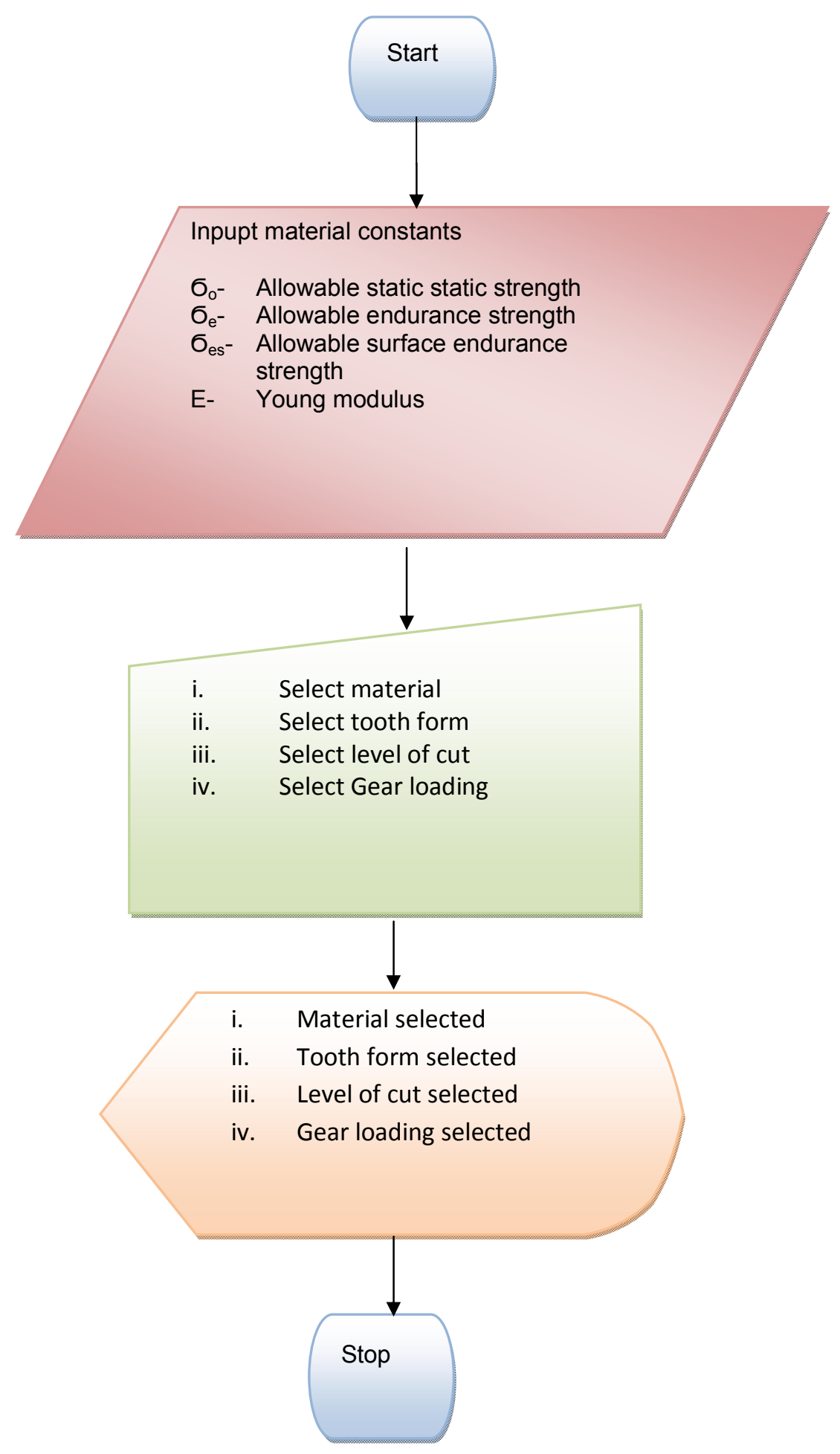




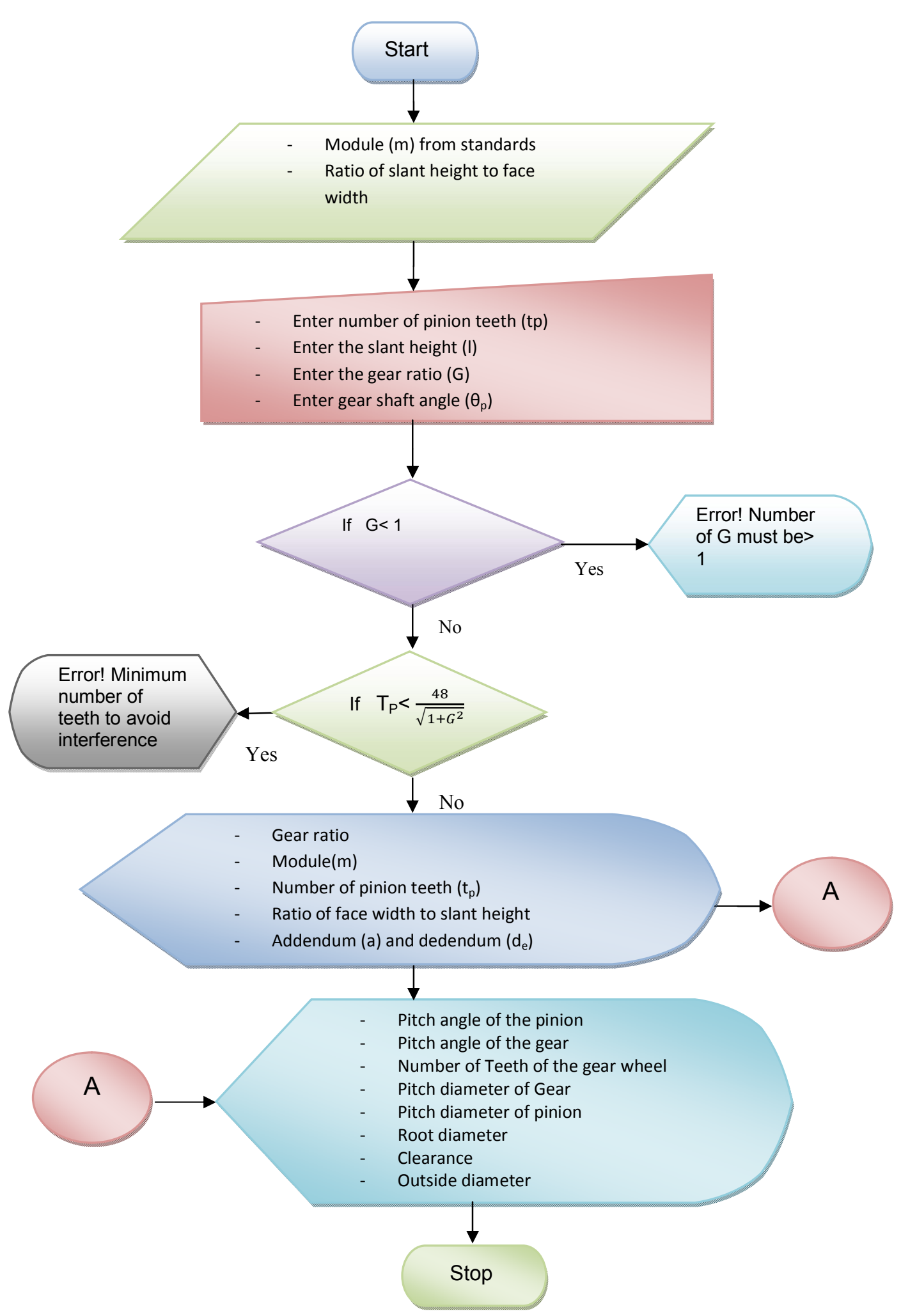




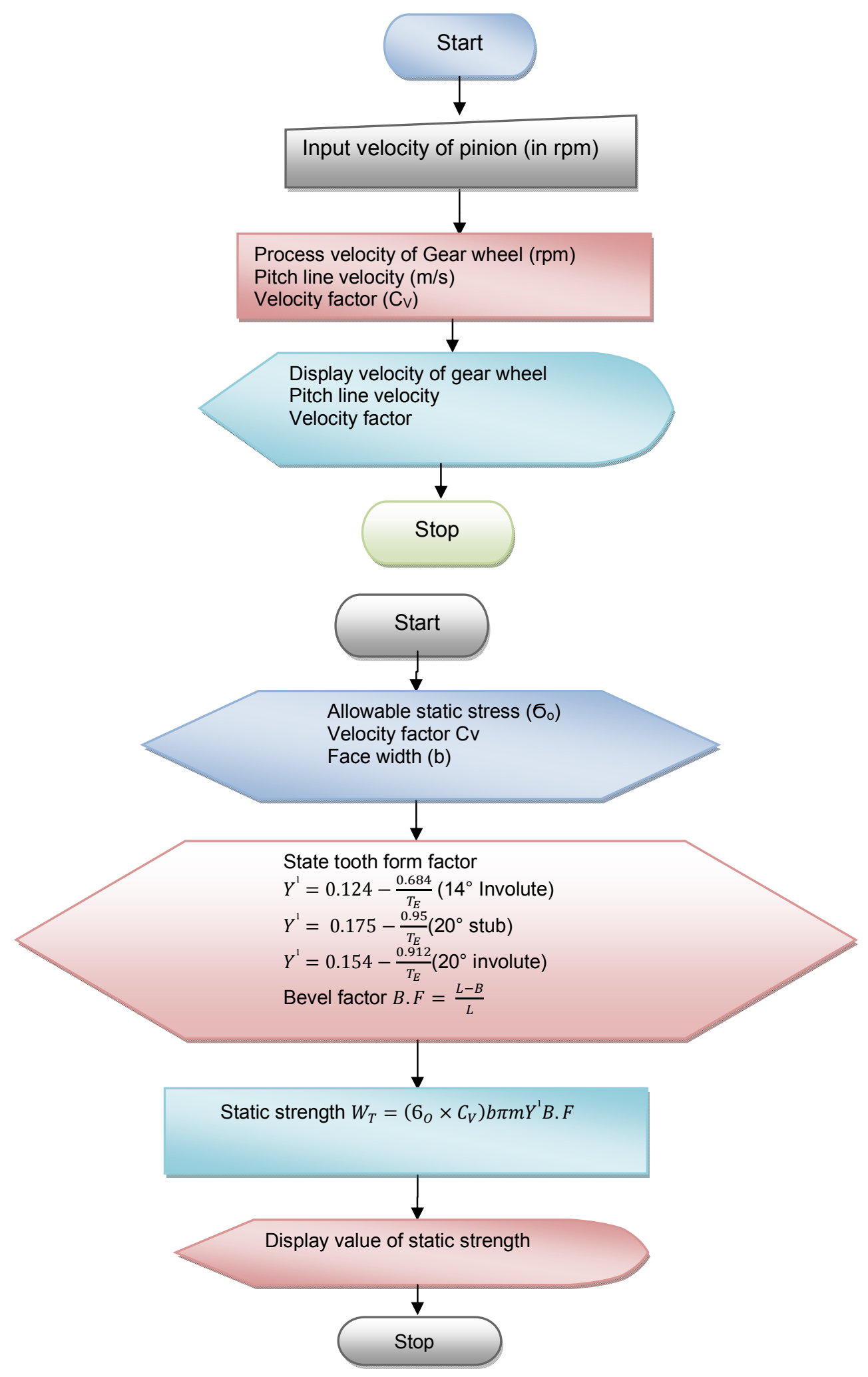




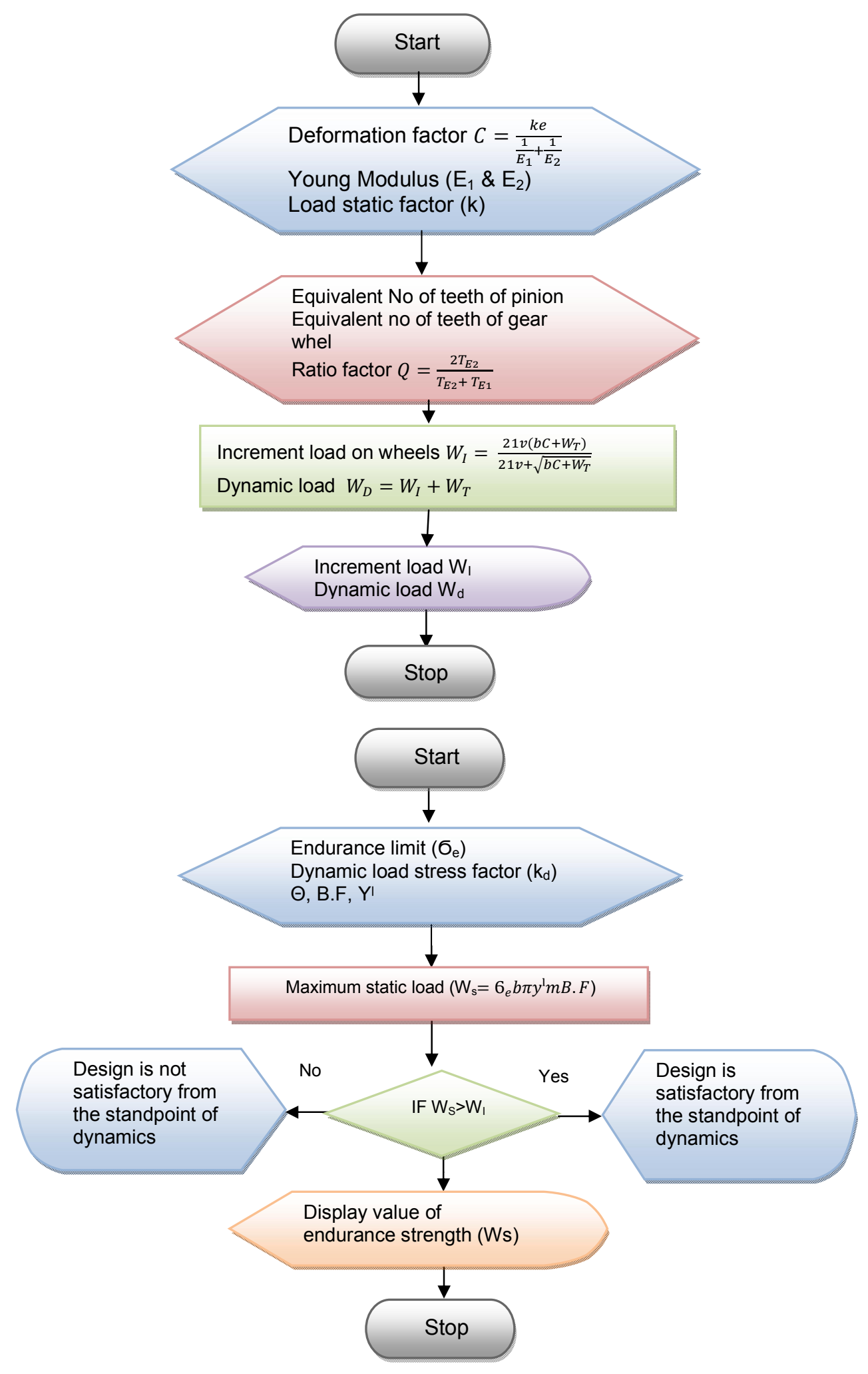




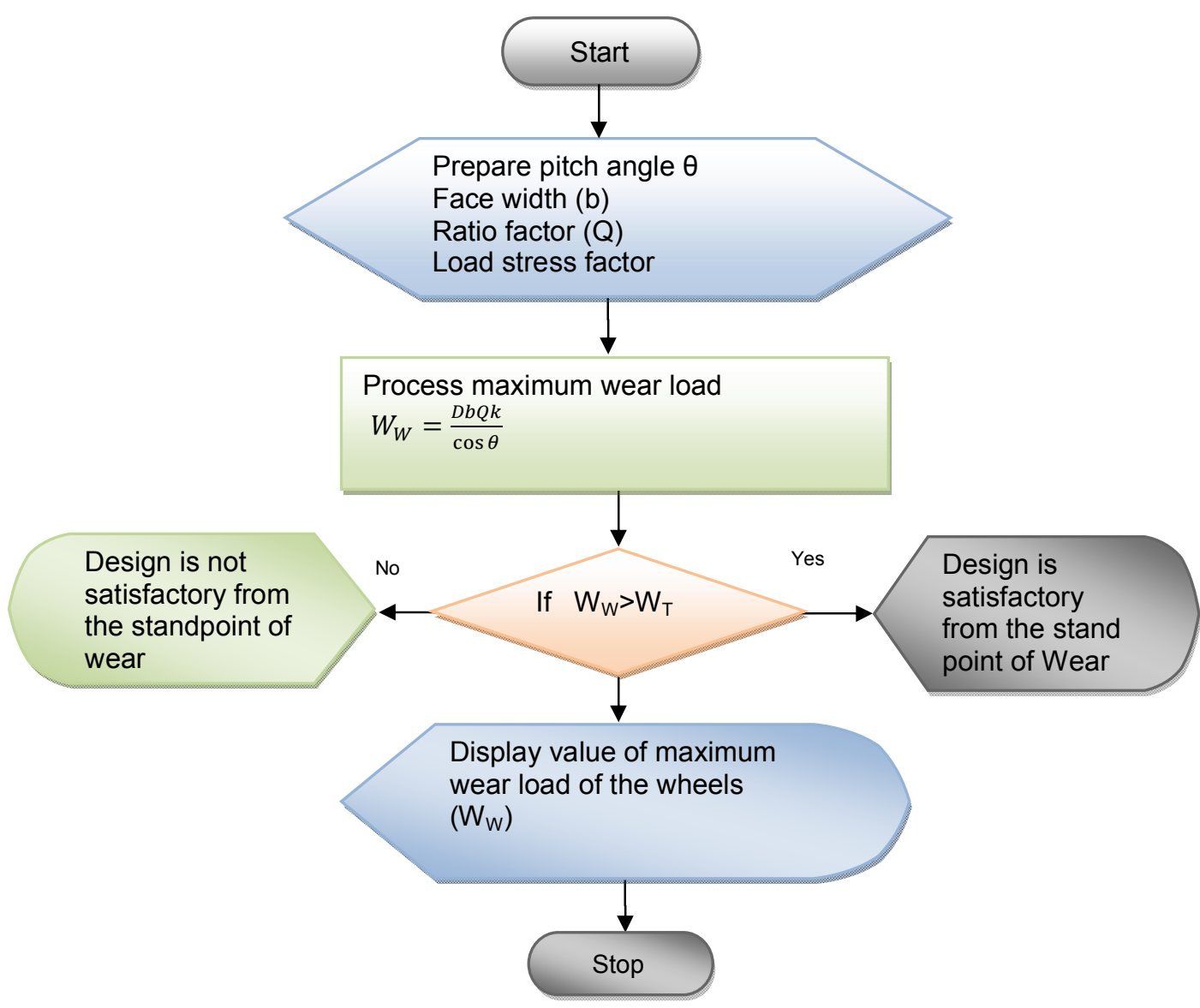

Fig. 3.0. Algorithm flow chats

\subsection{Software Development}

The algorithm above was used to develop the software (Bevel CAD) used in the design of bevel gear. This was made possible by transforming the required formulas and data of bevel into a set of instruction codes. The codes written could validate the user inputs and respond by giving the user the necessary information. The software was designed using C\# programming language and the Net Platform. The .Net Platform is a new and efficient platform from Microsoft cooperation that is invented to fill in the deficiency gap created by its predecessor platform like Win 32, MFC, Visual Basic, to name but few.

\subsubsection{Reasons for using net platform}

The .Net is preferred over other platforms due to the following reasons:

1. It is neutral language. Numerous languages can be employed to write programs on this platform. There are over 250 programming languages presently available. Microsoft created four out of this. They are C\#, VB. Net, J\#, C++/CLI).

2. The platform is fully object oriented and this accounts for its unmatched ability in managing the automation of the most complex problems.

3. It is very secure. Security is planted at the core (most inner section) of the platform. 
Concerning its features, $\mathrm{C} \#$ inherited $70 \%$ of java, $5 \%$ of $\mathrm{VB}, 10 \%$ of $\mathrm{C} / \mathrm{C}++$, and it adds $15 \%$ new. The programs emulated good aspects of the suspect and became better software. This among other reasons lends credence for the selection C\# for designing Bevel CAD Designer.

\subsection{Main Window}

The Bevel CAD main window as shown in Fig. 4.0 consists of four tabs as listed and described below:

i. Material /Gear type

ii. Dimensions

iii. Speed and velocity

iv. Gear design

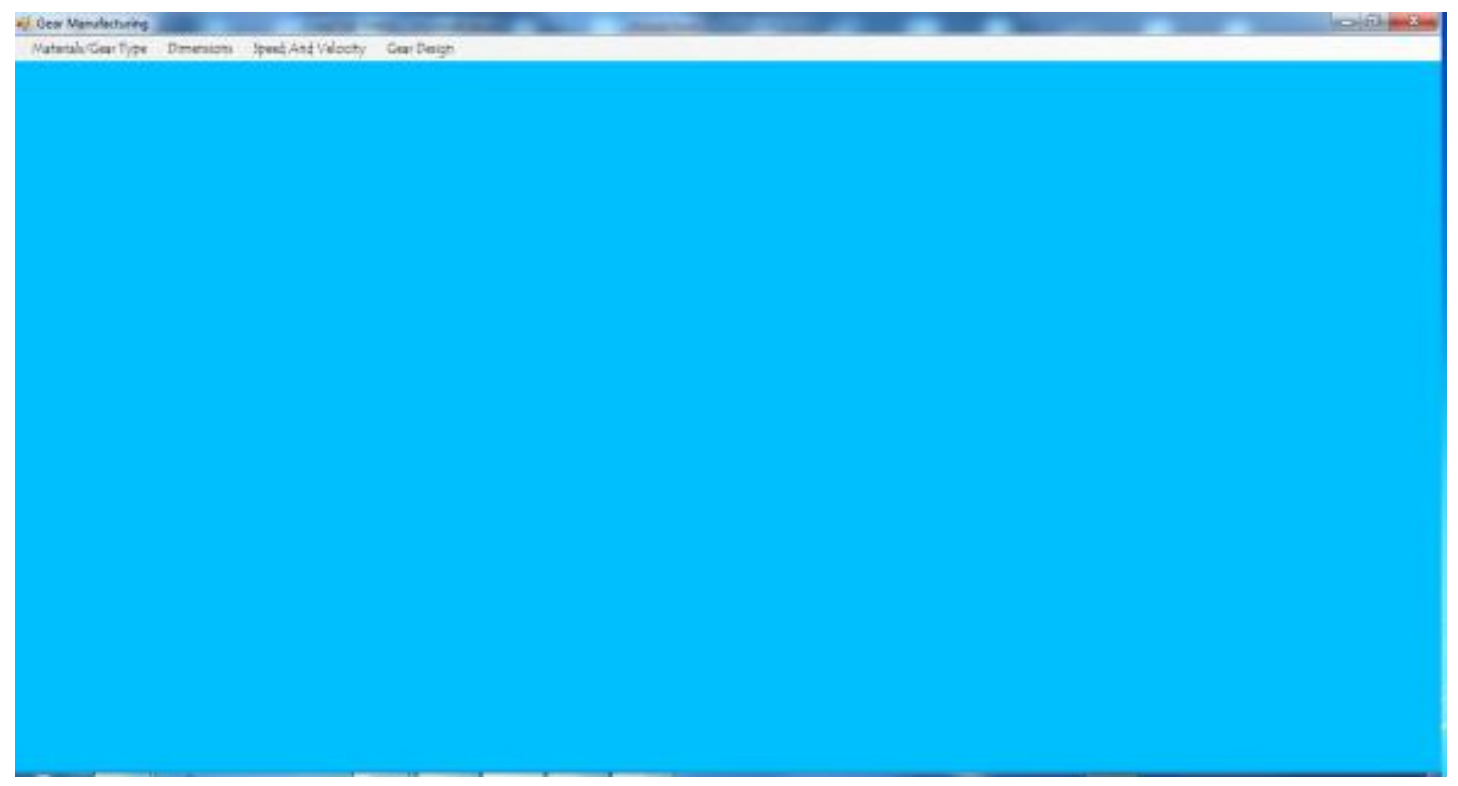

Fig. 4.0. Bevel CAD main window

\subsection{Material/Gear Type Interface}

The environment shown in Fig. 5.0 pops-up and request for the gear and the pinion and input information (parameter).

The parameter requested for include the following:

i Material- the material required include: cast iron of different grades, carbon steel, cast steel, aluminium steel, phosphor, bronze, alloy steel etc.

ii Select tooth form- the various types of tooth forms which include $: 20^{\circ} \mathrm{stub}, 20^{\circ}$ involute, $14.5^{\circ}$ involute

iii Level of cut- the accuracy of cut can be selected which include the following : precision cut, ordinary cut, carefully cut

iv Gear loading- this software makes available margins for the type of loading that the gear will be subjected. The gear loading types include pulsating load, steady load and shock load. 


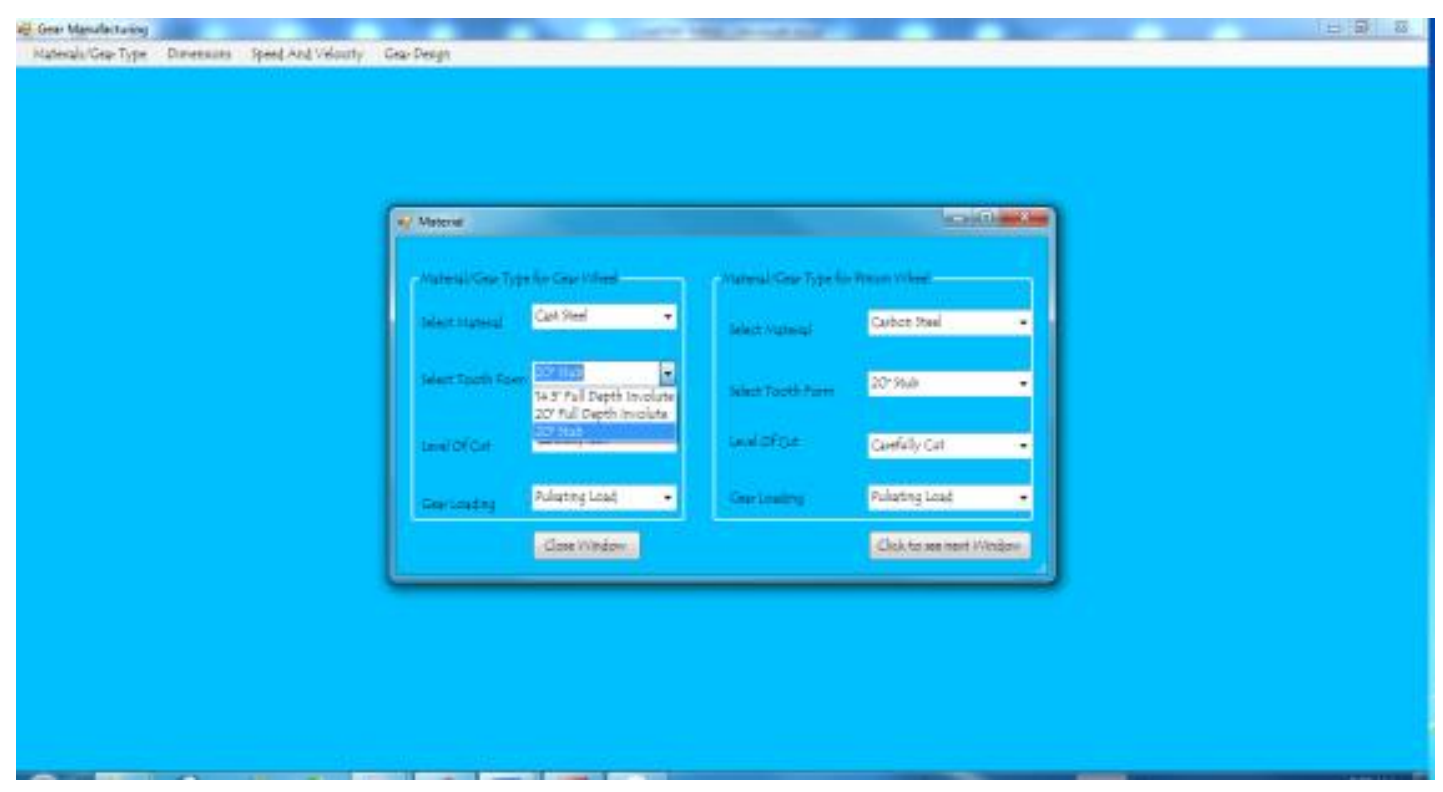

Fig. 5.0. Material/gear type environment

\subsection{Dimension Window}

The dimension window shows the interface of the inputs in the dimensions. The window is as shown in Fig. 6.0.

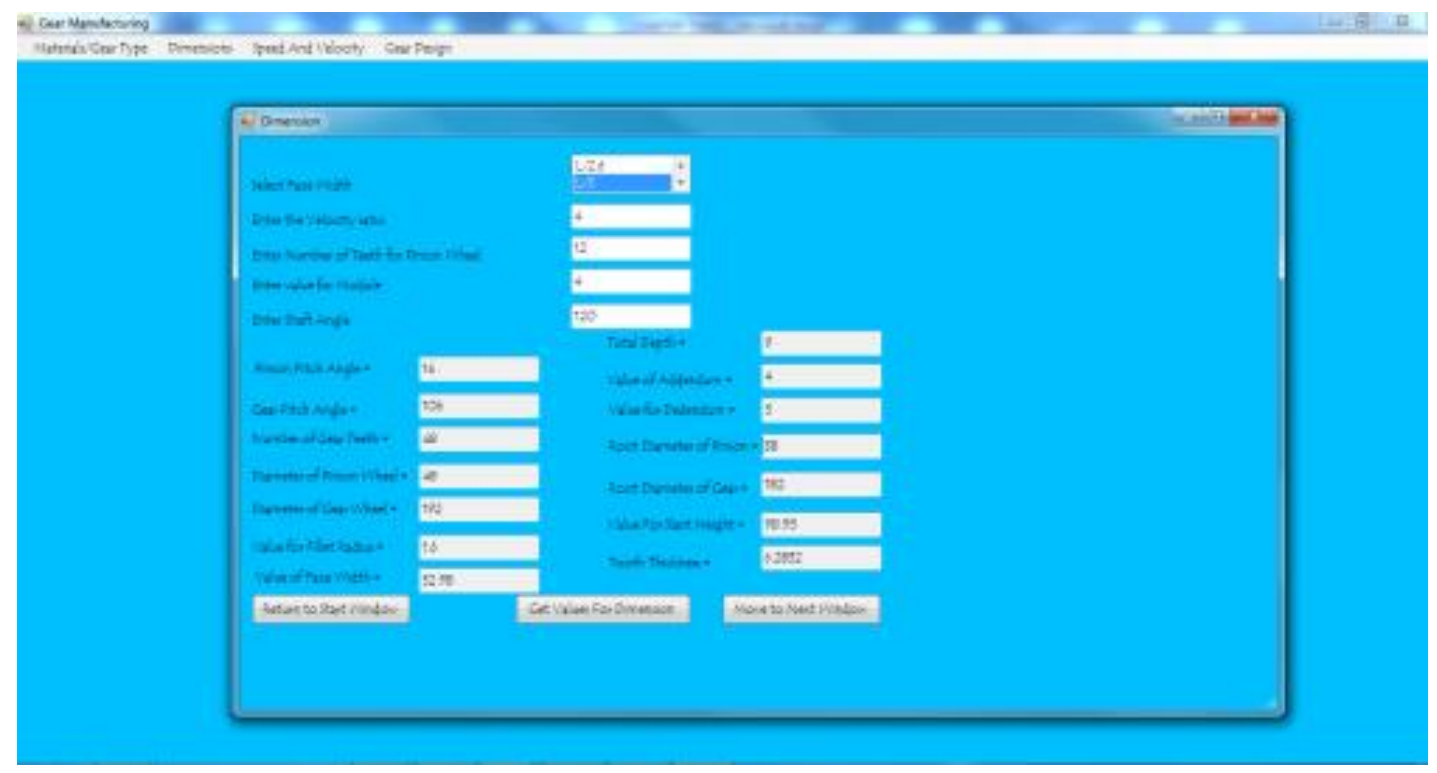

Fig. 6.0. Bevel CAD dimension interface

The software requires for the following input dimensions which include. 
i Ratio of the face-width to the slant height: The slant height ratio to face-width value is demanded for. Examples of these values are $(1 / 2,1 / 2.3,1 / 2.5,1 / 3,1 / 4)$.

ii Velocity Ratio: Also known as the Gear Ratio is also an input parameter in the design of the bevel gear

iii Number of Pinion Teeth: The software request for the number of the initiated pinion gear.

iv Enter the value of the module: The module value is also required for the design of bevel gear.

v Shaft angle: The software is capable of processing any form of bevel gear of different shaft angles of $90^{\circ}$, angular bevel gears $\left(120^{\circ}, 130^{\circ}, 125^{\circ}, 140\right.$ etc. $)$.

Clicking on the tab 'get value for dimension' the computer does the calculations in the algorithm and displays value for the following parameter. Pitch angle of pinion, pitch angle of gear, Number of pinion Teeth, Number of Gear teeth, diameter of gear teeth, diameter of pinion teeth, value of fillet radius, tooth depth, value of addendum, value of dedendum, root diameter of pinion, root diameter of gear, etc.

There are 2 other tabs in this window, making it the 3 tabs in this window. Clicking the tab "return to the start window" takes the designer back to the start window. Clicking the tab" Move to Next Window" popsup the "speed and velocity window".

\subsection{Speed and Velocity Window}

The window requires just the velocity of the pinion in rpm. The computer itself generates velocity of the gear wheel in rpm and the pitch line velocity of the pair of gears. The window also has 'move to the Next window' which takes the designer to the last phase called the 'gear design window'. Snap shot of the speed and velocity interface is shown in the Fig. 7.0.

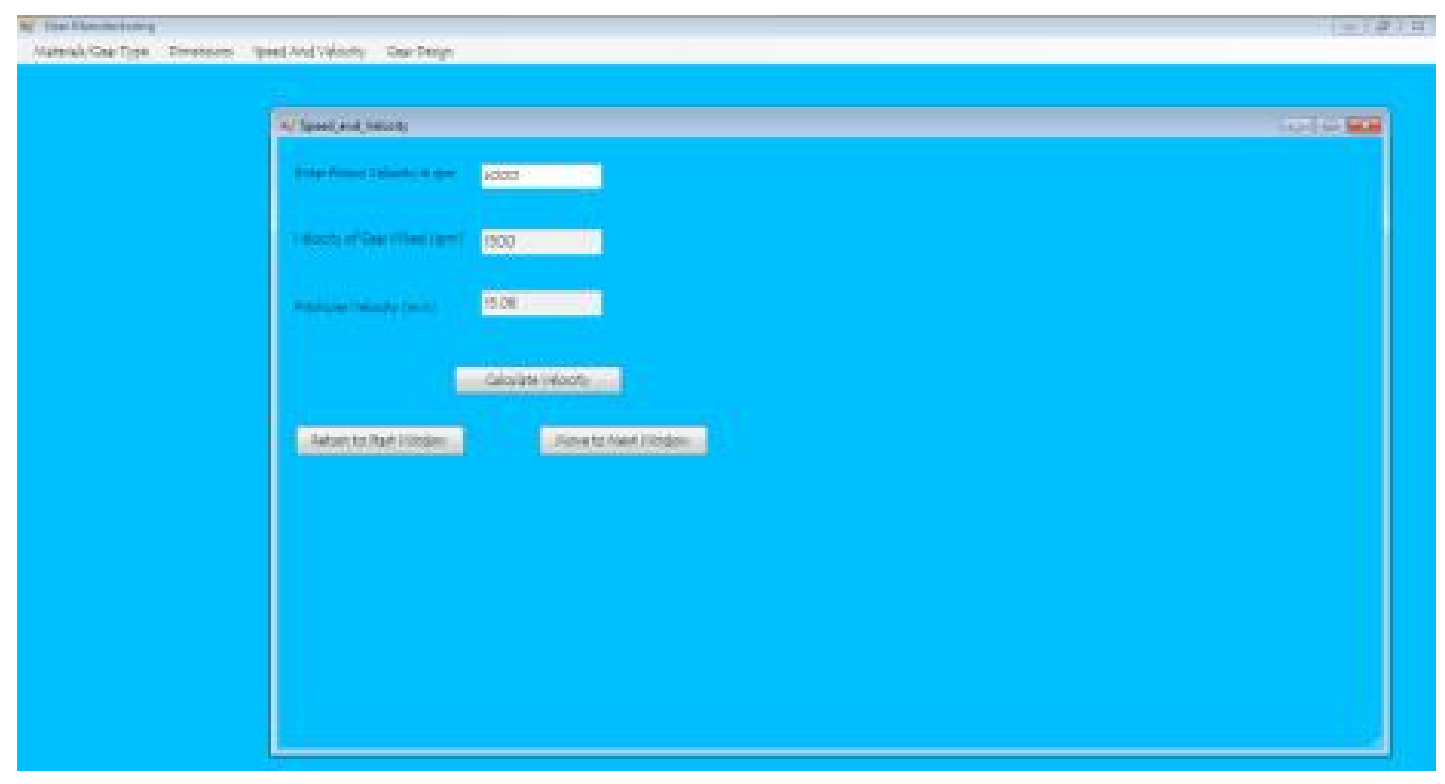

Fig. 7.0. Gear speed and velocity interface

\subsection{Gear Design Window}

This window is the main citadel of the software. The phase does not require for any input but uses the existing input to calculate and display the following gear characteristics. 
i Beam strength of pinion Tooth

ii Beam strength of Gear tooth

iii Deformation factor

iv Increment load of pinion wheel

$\mathrm{v}$ Dynamic load of pinion wheel

vi Dynamic load of Gear wheel

vii Endurance Strength of pinion wheel

viii Endurance Strength of Gear wheel

ix Maximum Wear load of pinion wheel

$x$ Maximum wear load of gear wheel

xi Load stress factor for pinion wheel

xii Load stress factor for gear wheel

xiii Ratio Factor

A snapshot of this window is shown in Fig. 8.0.

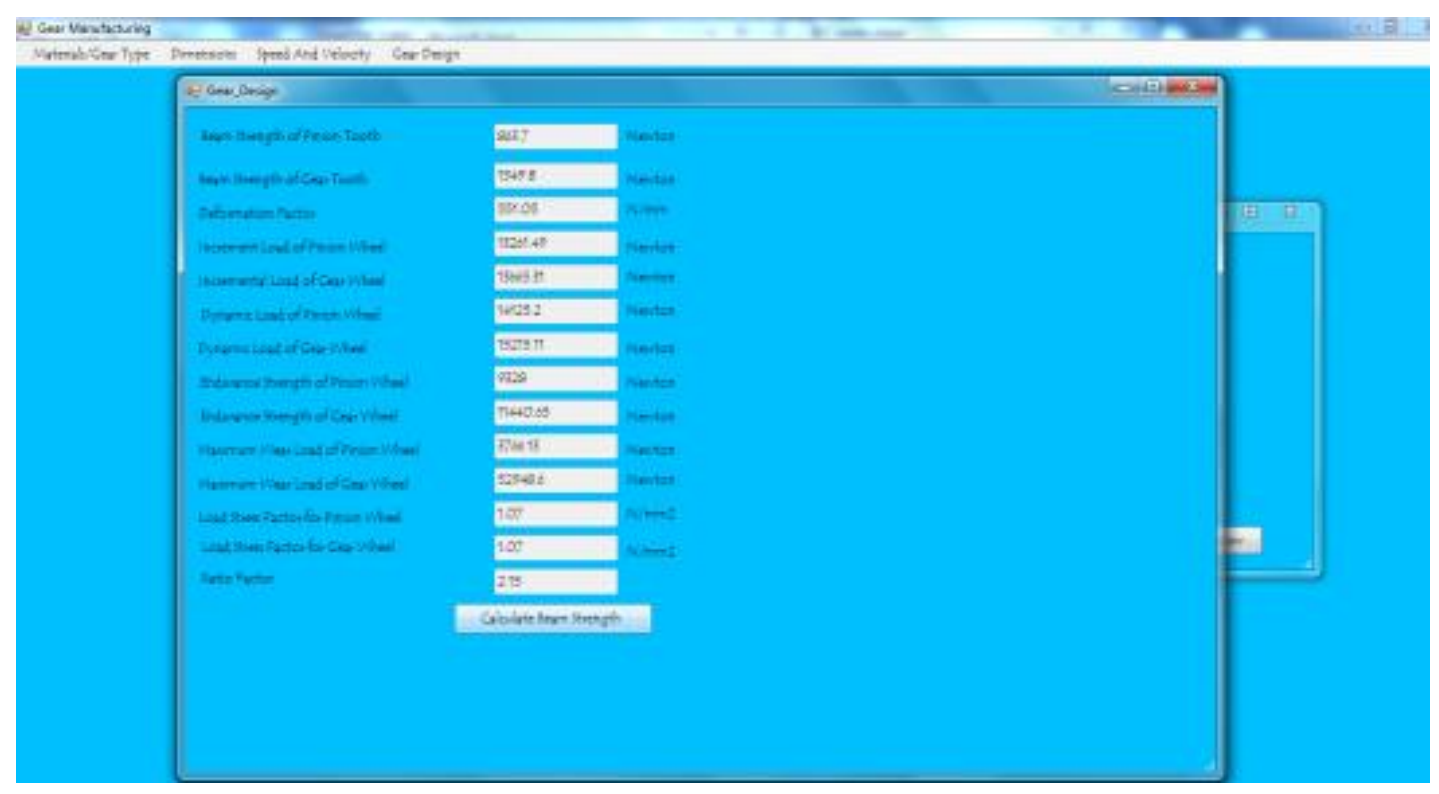

Fig. 8.0. The gear design window

The outstanding characteristics about this software is its ability to suggest to designer the conditions of the gear been designed in term of

i Stronger teeth among the pinion and the gear

ii Endurance characteristic of the teeth under dynamics.

iii Wear characteristic of the gear teeth under dynamic load.

Fig. 9.0 is a snapshot of condition suggested after a test designed using the Bevel CAD. 


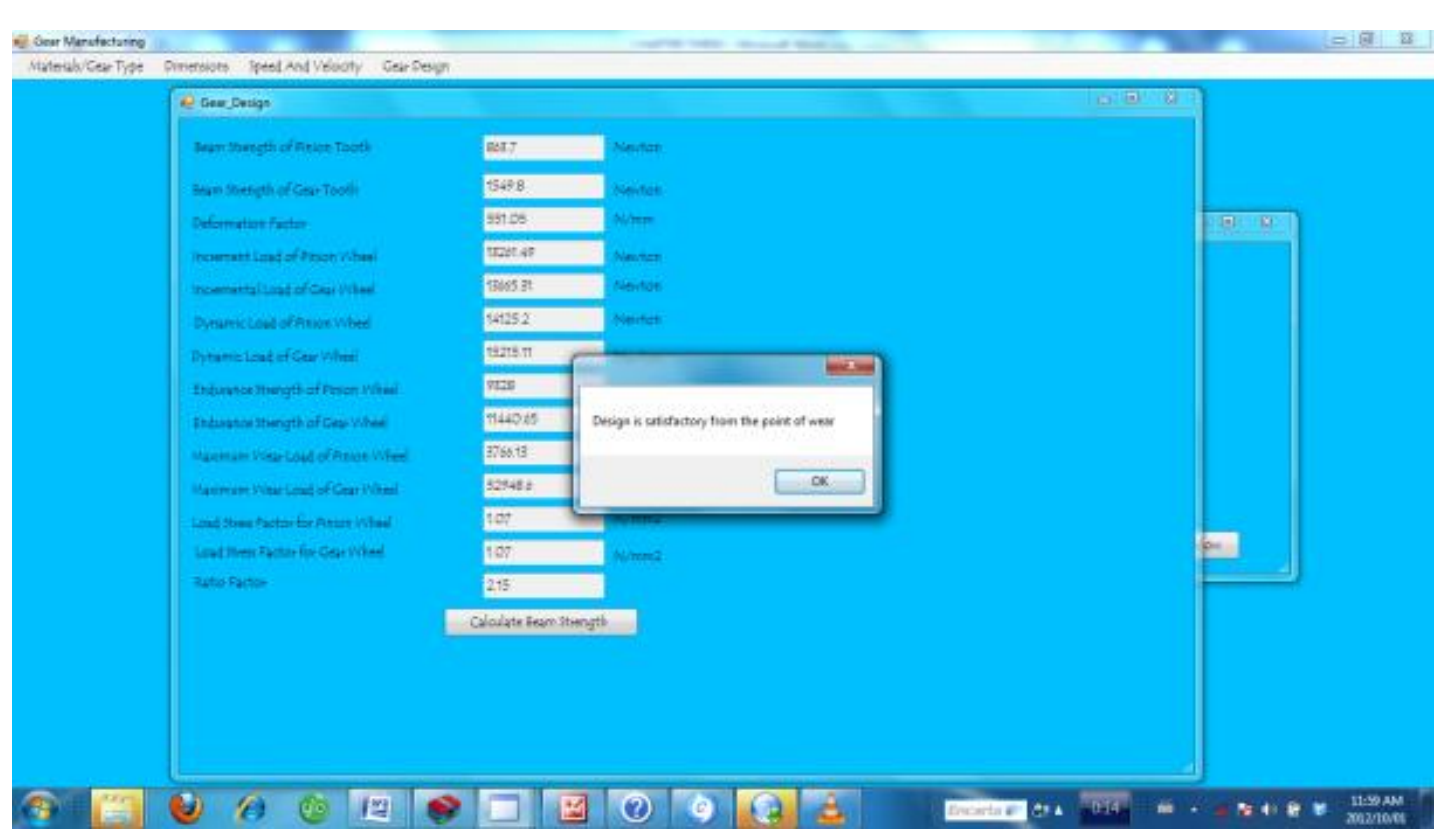

Fig. 9.0. Design condition snap-shot

\section{Results and Discussion}

The software was tested by comparing its result with the manually computed result using the same examples. The software found an excellently close answer with that of the result obtained from the textbook and the algorithm test above. The software was again tested with other inputs from renowned textbooks and similar/close answers were also gotten. The little differences in the answers were due to errors due to approximation. See Table 3.0 for the results of the manually computed results and Bevel CAD results.

\subsection{Design of Bevel Gear}

Material used for both Pinion and Gear wheel =Cast iron grey, Carefully cut with stead loading. Velocity ratio/gear ratio $=1.25$, module $=5 \mathrm{~mm}$, Number of teeth in the Pinion wheel $=16$, Angle of shaft $=90^{\circ}$, Speed of pinion wheel $=1100 \mathrm{rpm}$.

Table 3.0. Comparism between the results

\begin{tabular}{llll}
\hline S/n & Parameters & $\begin{array}{l}\text { Value from manual/hand } \\
\text { computation }\end{array}$ & $\begin{array}{l}\text { Values from bevel } \\
\text { CAD software }\end{array}$ \\
\hline 1 & Pinion pitch angle & $38.66^{\circ}$ & $39^{\circ}$ \\
2 & Gear pitch angle & $51.34^{\circ}$ & $51^{\circ}$ \\
3 & Number of gear teeth & 20 & 20 \\
4 & Diameter of pinion wheel & $80 \mathrm{~mm}$ & $80 \mathrm{~mm}$ \\
5 & Diameter of gear wheel & $100 \mathrm{~mm}$ & $100 \mathrm{~mm}$ \\
6 & Fillet radius & $2 \mathrm{~mm}$ & $2 \mathrm{~mm}$ \\
7 & Face width & $21.34 \mathrm{~mm}$ & $21.34 \mathrm{~mm}$ \\
8 & Total depth & $11.25 \mathrm{~mm}$ & $11.25 \mathrm{~mm}$ \\
9 & Addendum & $5 \mathrm{~mm}$ & $5 \mathrm{~mm}$ \\
10 & Dedendum & $6.25 \mathrm{~mm}$ & $6.25 \mathrm{~mm}$ \\
11 & Root diameter of pinion & $67.5 \mathrm{~mm}$ & $67.5 \mathrm{~mm}$ \\
\hline
\end{tabular}


Table 3.0 continued........

\begin{tabular}{|c|c|c|c|}
\hline 12 & Root diameter of gear & $87.5 \mathrm{~mm}$ & $87.5 \mathrm{~mm}$ \\
\hline 13 & Slant height & 64.03 & 64.03 \\
\hline 14 & Tooth thickness & $7.854 \mathrm{~mm}$ & $7.854 \mathrm{~mm}$ \\
\hline 15 & Velocity of gear & $880 \mathrm{rpm}$ & $880 \mathrm{rpm}$ \\
\hline 16 & Pitch line velocity & $4.61 \mathrm{~m} / \mathrm{s}$ & $4.61 \mathrm{~m} / \mathrm{s}$ \\
\hline 17 & $\begin{array}{l}\text { Beam strength of pinion } \\
\text { tooth }\end{array}$ & $796.9 \mathrm{~N}$ & $796.06 \mathrm{~N}$ \\
\hline 18 & Beam strength of gear tooth & $911.03 \mathrm{~N}$ & $916.98 \mathrm{~N}$ \\
\hline 19 & Deformation factor & 302.28 & 302.27 \\
\hline 20 & $\begin{array}{l}\text { Incremental load of pinion } \\
\text { wheel }\end{array}$ & $3856.42 \mathrm{~N}$ & $3855.52 \mathrm{~N}$ \\
\hline 21 & $\begin{array}{l}\text { Incremental load of gear } \\
\text { wheel }\end{array}$ & $3905.18 \mathrm{~N}$ & $3902.25 \mathrm{~N}$ \\
\hline 22 & $\begin{array}{l}\text { Dynamic load of pinion } \\
\text { wheel }\end{array}$ & $4653.32 \mathrm{~N}$ & $4651.59 \mathrm{~N}$ \\
\hline 23 & Dynamic load of gear wheel & $4822.16 \mathrm{~N}$ & $4813.28 \mathrm{~N}$ \\
\hline 24 & $\begin{array}{l}\text { Endurance strength of pinion } \\
\text { wheel }\end{array}$ & $2056.52 \mathrm{~N}$ & $2056 \mathrm{~N}$ \\
\hline 25 & $\begin{array}{l}\text { Endurance strength of pinion } \\
\text { wheel }\end{array}$ & $2366.41 \mathrm{~N}$ & $2352.56 \mathrm{~N}$ \\
\hline 26 & $\begin{array}{l}\text { Maximum wear load of } \\
\text { pinion wheel }\end{array}$ & $4027.6 \mathrm{~N}$ & 4002.59 \\
\hline 27 & $\begin{array}{l}\text { Maximum wear load of gear } \\
\text { wheel }\end{array}$ & $6293.05 \mathrm{~N}$ & $6208.09 \mathrm{~N}$ \\
\hline
\end{tabular}

Comparing the manually calculated results with the CAD result, the following inferences are made:

\subsection{Accuracy in Calculations}

Very close results were generated by both the manual calculation and that of the CAD software. The modeled calculation is believed to be more accurate because it uses uniform approximation in all its results.

\section{$\underline{4.2 .1 ~ R e d u c t i o n ~ i n ~ e r r o r s ~ a n d ~ t i m e ~ s a v i n g s ~}$}

In addition to the accuracy of the software, errors and mistakes in computations were drastically reduced. Care must be taken in the calculations as the designers are proned to mistakes due to complex calculations. Hand calculation takes a lot of time. From Table 3.0, it is observed that manual hand calculation takes average of 52 minutes to design a typical bevel gear but the same design takes just an average of 11 minutes when using Bevel CAD Designer software.

\subsubsection{Suggestion of design conditions to designers}

The modeled software also suggests the physical condition of the designed bevel gear using the computed result. These suggestions help designers to achieve better designs.

\section{Conclusion and Recommendations}

The required parameters for the design of bevel gears were identified which led to the formation of mathematical models. Algorithm was developed from the model which was later transformed to Bevel CAD software. 
The developed software was evaluated by comparing its results by the manual mathematical computation and the results were found to be similar. Apart from the fact that the software saves time for the parametric design of bevel gear, it also suggests design conditions to assist bevel gear designers in decision making. Human errors are eliminated using the software.

It is recommended that the software be introduced to the tertiary institutions as a teaching aid to student on gear design and also designers should give proper considerations to design conditions suggested by the software to aid proper designs.

\section{Competing Interests}

Authors have declared that no competing interests exist.

\section{References}

[1] Hamrock Bernard J, Steven R Schmid, Bo OJ. Fundamentals of machine elements. $2^{\text {nd }}$ Ed. New York: McGraw-Hill; 2005.

[2] Han D, Xieeryazidan A. New modeling methods of spiral bevel and hypoid gear based on the CAD surface design features. Recent Advances in Computer Science; 2014.

[3] Li J. Study on basic applied technology in the process of digitized manufacturing for spiral bevel and hypoid gear. Tianjin University; 2008.

[4] Groover MP, Emory W, Zimmers JR. CAD/CAM computer aided design and manufacturing. Original U.S Ed. Prentice- Hall Inc: Englewood cliffs N.J; 1992.

[5] Geotsch DL, Richman RL. Computer- aided design and drafting. Merrill Publishing Company. Columbus; 1990.

[6] Antoniadis. Gear skiving-CAD simulation approach. Computer-Aided Design. 2012;44:611-616.

[7] Zeng T. Design and manufacture of spiral bevel and hypoid and hypoid gear. Harbin Institute of Technology Press; 1989.

[8] Erdman GA, Sandor NG. Mechanism design analysis and synthetic. $1^{\text {st }}$ Ed. Hall of India private limited. 1984;1.

[9] Bartłomiej S, Adam M. Method of spiral bevel gear tooth contact analysis performed in CAD. Aircraft Engineering and Aerospace Technology. 2013;85(6):467-74.

[10] Julien A, Jérôme G, Emmanuel M, Marc S. A simple and robust method for spiral bevel gear generation and tooth contact analysis. International Journal on Interactive Design and Manufacturing. 2013;7(1):37-49.

[11] Qi F, Ron D. Gleason Expert Manufacturing System (GEMS): Open a new era for digitized manufacturing of spiral bevel and hypoid and hypoid gear. World Manufacturing Engineering \& Market. 2005;4:87-93.

[12] Shingley JE, Mischke RC. Machine design fundamentals. $5^{\text {th }}$ Ed. McGrawhill Inc.: NewYork; 1986.

[13] Shuangxi X. A genuine face milling cutter geometric model for spiral bevel and hypoid gears. The International Journal of Advanced Manufacturing Technology. 2013;67:2619-26. 
[14] Anonymous. How stuff works. Accessed April $2^{\text {nd }} 2015$. Available: http://science.howstuffworks.com/transport/engines-equipment/gear4.htm

[15] Khurmi RS, Gupta JK. Textbook on machine design. $5^{\text {th }}$ Ed. S. Chand Eurasia Publishing House (PVT.) LTD.: Ram Nagar, New Delhi; 2005.

(C) 2015 Akinnuli et al.; This is an Open Access article distributed under the terms of the Creative Commons Attribution License (http://creativecommons.org/licenses/by/4.0), which permits unrestricted use, distribution, and reproduction in any medium, provided the original work is properly cited.

Peer-review history:

The peer review history for this paper can be accessed here (Please copy paste the total link in your

browser address bar)

http://sciencedomain.org/review-history/9852 